\title{
ULTRASTRUCTURAL ASPECTS IN PERITHECIA HYPHAE SEPTAL PORES OF GLOMERELLA CINGULATA F. SP. PHASEOLI
}

\author{
María Gabriela Roca M. ${ }^{*}$; Maria das Graças Ongarelli ${ }^{2}$; Lisete Chamma Davide ${ }^{1}$; Maria Cristina Mendes-Costa ${ }^{1}$ \\ ${ }^{1}$ Laboratório de Biologia Celular e Citogenética, Departamento de Biologia, Universidade Federal de Lavras, Lavras, MG, \\ Brasil. 'Departamento de Química, Escola Superior de Agricultura “Luiz de Queiroz”, Piracicaba, São Paulo, Brasil
}

Submitted: October 08, 1999; Returned to authors for corrections: February 02, 2000; Approved: August 30, 2000

\section{SHORT COMMUNICATION}

\begin{abstract}
Glomerella cingulata (Stonem.) Spauld. \& Schrenk f. sp. phaseoli, better known in its anamorphic state Colletotrichum lindemuthianum (Sacc. \& Magn.) Briosi \& Cav., is a causal agent of anthracnose in beans (Phaseolus vulgaris L.). Ultrastructural aspects of the perithecial hyphae of this pathogen were studied. The perithecia hyphae septal pores were found either plugged by a vesicle or unplugged. Some perithecia hyphae septa presented no pore. The Woronin bodies, close to the septal pores, appeared as globose structures which were more electron dense than the occlusions plugging the septal pore.
\end{abstract}

Key words: Glomerella cingulata, Colletotrichum lindemuthianum, transmission electron microscopy , septal pores, bean anthracnose

Glomerella cingulata (Stonem.) Spauld. \& Schrenk f. sp. phaseoli is the telomorphic state of Colletotrichum lindemuthianum (Sacc. \& Magn.) Briosi \& Cav. (16). This organism is found in nature only in its anamorphic state, which is considered a causal agent of anthracnose in beans (Phaseolus vulgaris $\mathrm{L}$.) (11). The few studies available on the ultrastructure of this species are related with the anamorphic state $(4,10$, 12). A descriptive work of ontogeny of $G$. cingulata ascoma was carried out by Uecker (17) at the light microscope level. Glomerella has different anamorphic states and a controversial discussion exists in the classification of Colletotrichum at the species level $(1,14,16)$.

During an investigation on the ultrastructure of different ascomycetes (9), a pore was frequently found in the hyphae septa, which could be free or occluded (plugged). Doubts still remain about the origin of these occlusions (9). In Pyronemataceae (Pezizales), the ultrastructural aspect of hyphae septal pore and Woronin bodies have been shown to be important taxonomic characteristcs $(7,8)$. However, septa in Sporothrix species exhibited three types of pores, and results of transmission electron micrographs of septa confirm the heterogeneity of this genus (15). No data on the ultrastructural aspects of G. cingulata f. sp. phaseol were found.

The present investigation shows the ultrastructural aspects of the perithecia hyphae of $G$. cingulata f. sp. phaseoli. Three Brazilian isolates, obtained from infected bean pods in Goiânia (GO) and Lambari (MG), were maintained at $24^{\circ} \mathrm{C}$ on media described by Junqueira et al. (6). After 7 days, entire perithecia (dark-group-mass) were picked from agar media, fixed with $2.5 \%$ glutaraldehyde $/ 2 \%$ paraformaldehyde in $0.05 \mathrm{M}$ sodium cacodylate buffer $\mathrm{pH} 7.2$, post fixed with $1 \%$ osmium tetraoxide, dehydrated in a graded acetone series, and embedded in Polybed. Ultrathin sections were obtained using a microtome equiped with a glass knife and stained with uranyl acetate and lead citrate. Sections were observed using a ZEISS-EM109 transmission electron microscope.

\footnotetext{
* Corresponding authorm. Mailing address: Laboratório de Citogenética e Biologia Celular, Departamento de Biologia, Caixa Postal 37, CEP 37200-000, Lavras, MG, Brasil. E-mail: mariagrm@ufla.br
} 
The septa in the perithecia hyphae frequently didn't present pores, in some cases they could be seen out of the plane of section. When the septa were continuous, they presented a narrowed area in the middle (Fig. 1) or a loop in the cell wall (Fig. 2). The septal perithecia hyphae were also found with a central simple septal pore (Fig. 3) and with occlusions at the pore (Fig.4). These occlusions were double layered vesicles and sometimes presented a convex band. The convexity varied from a hemisphere (Fig. 4) to a straight line.

Woronin bodies were frequently seen near the septal pore of the hyphae perithecia, but also near the wall, in other regions of the hyphal cell. These bodies were always globose.

Structures like Woronin bodies were sometimes found adjacent to the septa, showing a kind of fusion or integration with the hyphae septal material. When the hypha septal pores were without plugs, the appearance of the pore resembled a residual wall or with disintegrated vesicle material in this area.
In all observations, the occlusions found at the hyphae perithecia septal pore presented a different eletrodensity than the Woronin bodies.

In other studies, the types of septal pore occlusions in ascogenous hyphae were highly variable, even within the same species (9). The form of septal pore structures changed according to the stage of development of ascogenous hyphae and asci, and occlusions occurred at the basis of asci prior to spore delimitation (12). These characteristics could define the cell differentiation or function through the control of cytoplasmatic changes in adjacent cells. Only mature perithecia were used in our work, which may explain why septal pore occlusions at the base of the ascus were of the simple hemispherical type.

Berndt and Oberwinkler (3) considered that in ascomycetes mycorrhiza the septal pore occlusions perhaps act as a faster process to isolate cells, but enlarged pores may be impossible
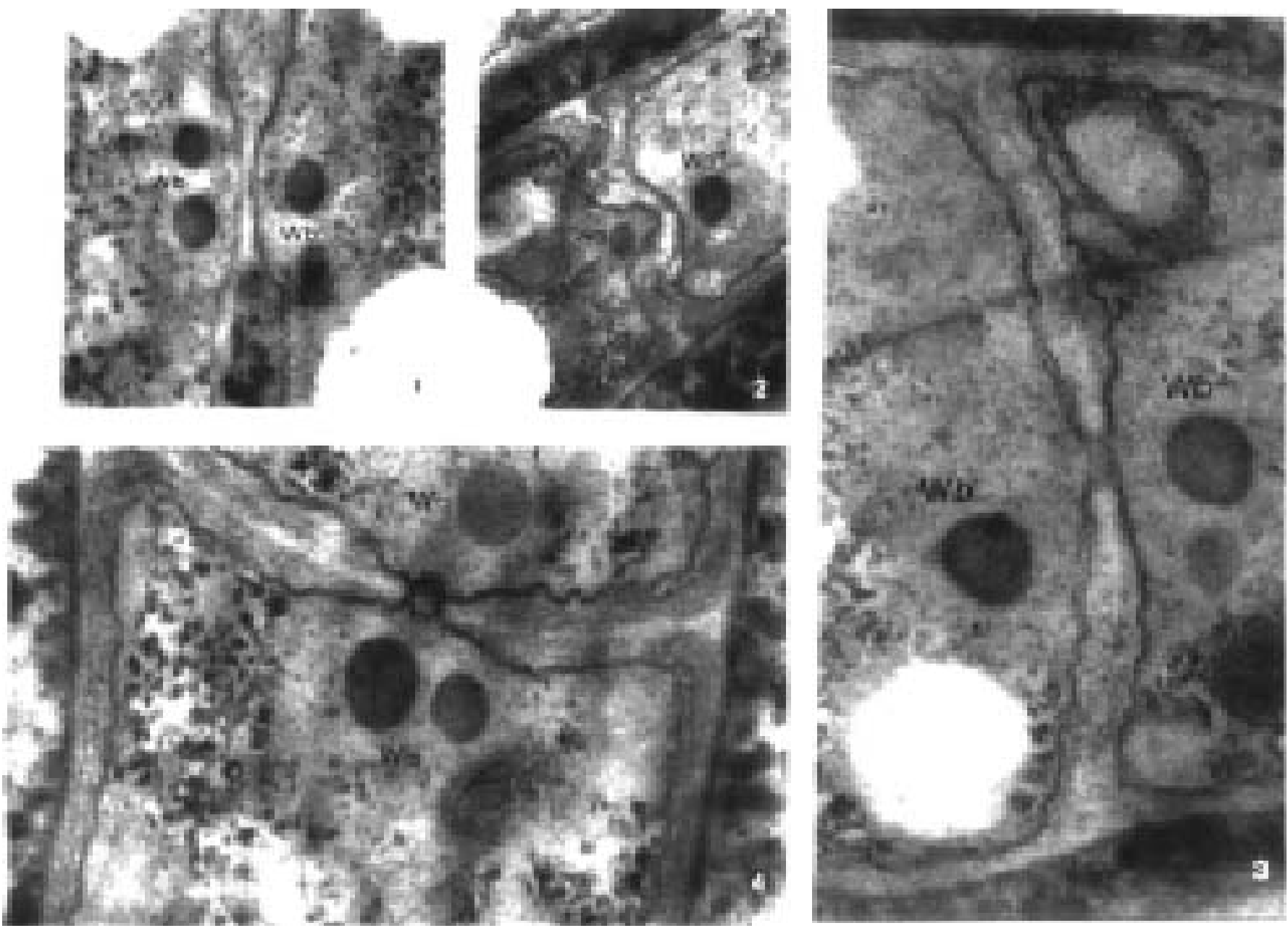

Figures 1-4: Glomerella cingulata f. sp. phaseoli ultrastructural aspects of septal pores. 1. Septum with a narrowed area in the middle. 34.350x; 2. Wall and plasma membrane loop in the septum. 34.350x.; 3. Residual membrane at the perforated septum. 69.220x; 4. Hemisphericaldouble-layered occlusion at the septum pore and Woronin bodies. 49.800x. (Wb, Woronin bodies). 
to be plugged with a Woronin body as described by Benny and Samuelson (2) in other fungi. In the perithecial hyphae, the dynamics of septa also show their participation in hyphal differentiation using the control of passage at the perithecia hyphae septal pore and the Golgi-like-membranes. These membranes could be working in the compartment of secretory products and the transformation of cytomembranes, as occurs in plants (5).

In conclusion, the perithecium hyphae of $G$. cingulata $\mathrm{f}$. sp. phaseoli may present discontinuous septa with pores, or continuous septa. The septal pores may be plugged by an occlusion, with only one kind of occlusion per septal pore. The Woronin bodies seem to never have the same characteristics as the occlusions. These characteristics are specific to the mature perithecia of this species.

\section{ACKNOWLEDGMENTS}

We are grateful to Dr. Ludwig Pfenning (UFLA) and Prof. Fernanda Bacellar (ESALQ/USP) for the discussions and suggestions during the preparation of the manuscript. This work was supported by grant from Brazilian National Research Council - CNPq and FAPEMIG.

\section{RESUMO}

\section{Ultraestrutura dos poros septais em hifas de peritécios de Glomerella cingulata f. sp. phaseoli}

Glomerella cingulata (Stonem.) Spauld. \& Schrenk f. sp. phaseoli, conhecida no seu estado anamórfico como Colletotrichum lindemuthianum (Sacc. \& Magn.) Briosi \& Cav., é agente causal da antracnose do feijoeiro (Phaseolus vulgaris L.). Aspectos ultraestruturais das hifas do peritécio deste patógeno foram observados. Os poros dos septos das hifas do peritécio apresentaram-se obstruídos com uma vesícula ou livres. Alguns septos das hifas do peritécio foram observados sem poros. Os corpos de Woronin, próximos aos poros dos septos, mostraram-se como estruturas globosas mais eletrodensas que as obstruções encontradas nos poros.

Palavras-chave: Glomerella cingulata, Colletotrichum lindemuthianum, microscopia eletrônica de transmissão, poros septais, antracnose do feijoeiro.

\section{REFERENCES}

1. Arx, J. A. V. Die Arten der Gattung Colletotrichum Cda. Phytopath. Z. 29 413-468. 1957.

2. Benny, G. L.; Samuelson, D. A. Ultrastructure of septa in the vegetative hyphae of Chaetomidium arxii and Phillipsia domengensis (Ascomycotina). Mycologia 72: 836-840. 1980.

3. Berndt, R.; Oberwinkler, F. Ultrastructure of septal pores of Mycorrhizaforming Ascomycetes. Mycologia 84: 360-366. 1992.

4. Bianchi, A.; Zambonelli, A.; D'Aurelio, A. Z.; Bellesia, F. Ultrastructural studies of the effects of Allium sativum on phytopathogens. Plant Disease 8 : 1241-1246. 1997.

5. Cunningham, W. B.; Morré, D. J. Mollehauer, H. H. Structure of isolated plant Golgi apparatus revealed by negative staining. J. Cell Biol. 28: 169179. 1966.

6. Junqueira, N. T. V.; Chaves, G. M.; Zambolin, L.; Romeiro, R.; Gasparoto, L. Da S. Isolamento, cultivo e esporulação de Microcyclus ulei, agente etiológico do mal das folhas de seringueira. Rev. Ceres 31: 322-331. 1984.

7. Kimbrough, J. W.; Curry, K. J. Septal structures in apothecial tissues of the tribe Aleurieae in the Pyronemataceae (Pezizales, Ascomycetes). Mycologia 78: 407-417. 1986.

8. Kimbrough, J. W.; Curry, K. J. Septal structures in apothecial tissues of taxa in the tribes Scutellinieae and Sowerbyelleae (Pyronemataceae, Pezizales, Ascomycetes). Mycologia 78: 735-743. 1986.

9. Markham, P. Occlusions of septal pores in filamentous fungi. Mycol. Res. 98: 1089-1106. 1994.

10. Mercer, M. C.; Wood, R. K.; Greenwood, A. D. Ultrastructure of the parasitism of Phaseolus vulgaris by Colletotricum lindemuthianum. Physiol. Plant Pathology 5: 203-215. 1975.

11. Rava, A. C.; Sartorato, A. Antracnose. In: Rava, A. C.; Sartorato, A. (eds) Principais doenças do feijoeiro comum e seu controle. Empresa Brasileira de Pesquisa Agropecuaria, Brasília. 1994. p. 17-40.

12. Rawlinson, C. J.; Carpenter, J. M.; Muthyalu, G. Double-stranded RNA virus in Colletotrichum lindemuthianum. Trans. Brit. Mycol. Soc. 65: 305-341. 1975.

13. Read, N. D.; Beckett, A. Ascus and ascospore morphogenesis. Mycol. Res. 100: 1281-1314. 1996.

14. Samuels, G. J.; Seifert, K. A. The impact of molecular characters on systematics of filamentous ascomycetes. Ann. Rev. Phytopathol. 33: 37-67. 1995.

15. Smith, M. T.; Batenburg-Van der Vegte, W. H. Ultrastructure in septa in Blastobotrys and Sporothrix. Antonie Van Leeuwenhoek 51: 121-128. 1985.

16. Sutton, B. C. The genus Glomerella and its anamorph Colletotrichum. In: Bailey, J. A.; Jeger, M.J. (eds.) Colletotrichum: Biology, Pathology and Control. CAB International, Wallingford. 1992. p. 1-26.

17. Uecker, F. A. Ontogeny of the ascoma of Glomerella cingulata. Mycologia 86: 82-88. 1994. 